\title{
Poststructuralism in International Relations: Discourse and the Military
}

\author{
Mario Baumann
}

\section{Contents}

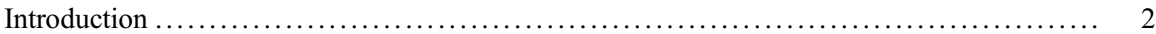

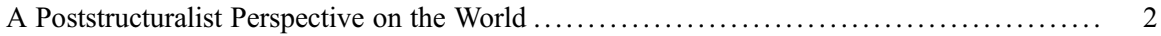

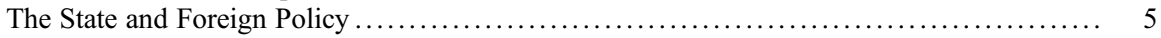

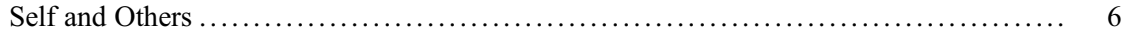

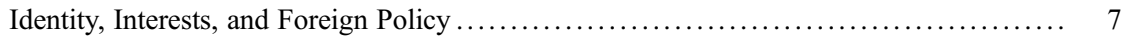

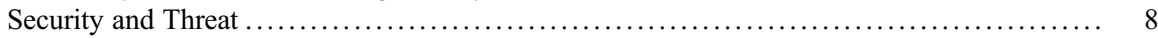

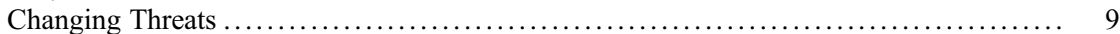

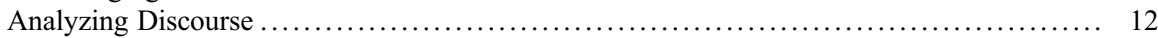

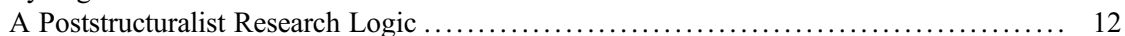

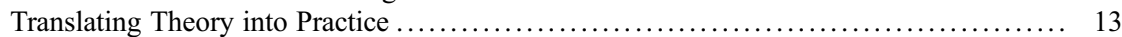

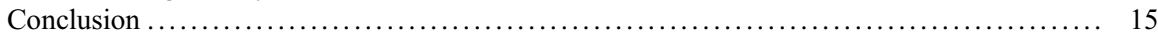

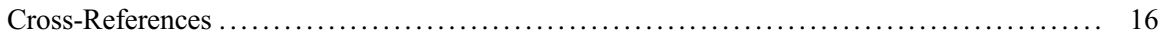

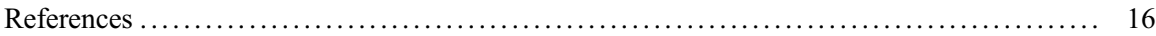

\section{Abstract}

This chapter introduces the poststructuralist perspective on international relations (IR). It outlines the epistemological and ontological fundament of poststructuralist thinking and introduces key concepts, notably discourse.

This chapter aims to show that the way we talk about the world, about ourselves and others matters. It employs a particular focus on issues and examples that relate to the military - a domain that for long has been dealt with from more traditional IR perspectives. It seeks to encourage to look at those issues from a different, more critical, angle. It touches upon questions like: Can we ever be fully secure or do we need threats? How did the Global War on Terror become thinkable? What is the relationship between humanitarian interventions and identity?

M. Baumann ( $ه)$

Brussels School of International Studies, University of Kent, Brussels, Belgium

e-mail:mb997@kent.ac.uk 
By presenting key contributions to the poststructuralist body of literature in IR, this chapter traces a poststructuralist perspective on issues of international relations, notably the state and foreign policy, security and threats. It encourages to scrutinize them critically and gives an overview of how to employ this theoretical perspective for empirical discourse analyses in practice.

\section{Keywords}

Poststructuralism · Discourse $\cdot$ Interpretation · Identity · Sovereignty $\cdot$ Security Securitization $\cdot$ Discourse analysis

\section{Introduction}

When former US President Donald Trump met with his Russian counterpart Vladimir Putin in Helsinki in 2018, he suddenly found himself confronted with the power of discourse. As a response to a journalist's question on whether he believed US intelligence agencies' accusations that Russia was meddling in United States' Presidential elections, Trump replied: "[President Putin] just said it's not Russia. [...] I don't see any reason why it would be" (Foreign Policy, 2018). His siding with Putin was met with a fierce backlash across the political spectrum in the United States, including in his own party. The Western discourse about Russian disinformation had produced a clear view on who was the perpetrator - Russia - and who was the victim - the United States. Irrespective of the actual circumstances of the US elections, this discourse made Trump's comment virtually unsayable - forcing him to awkwardly deny his remark only one day later (Baumann, 2020: 303; Landler \& Haberman, 2018). There is an intimate link between foreign policy and how we talk about ourselves and others. This is the terrain of poststructuralists in international relations. This terrain offers profound and critical insights to anyone seeking to make sense of international relations, including those in the military who are implicated in them on the ground. This chapter seeks to map this theoretical terrain by, first, introducing the basic tenets of the poststructuralist perspective. It will, secondly, trace poststructuralism's entry into the field of international relations (IR) by means of discussing "the state" and, thirdly, the poststructuralist take on "security." A final section will offer a brief guide to methodology, illustrating how to devise theorydriven analyses in practice.

\section{A Poststructuralist Perspective on the World}

How can we as researchers make sense of the world? Poststructuralism has emerged in part as a response to a more traditional research philosophy that informs other IR theories, such as Realism or Liberalism, as outlined in the preceding chapters (see chapters " $>$ Realist International Relations Theory and the Military" by B. Schmidt, this volume; " $>$ Liberal International Relations Theory and the Military" by 
S. Silverstone, this volume). The poststructuralist perspective on the world is different from the maybe more intuitive one adopted by those, often deemed positivist, theories. Positivist theories rest on the assumption that researchers have unmediated access to the "outside world." They presume that they can uncover "reality," objectively describe, and formulate true statements about it. Positivism is an epistemological position. Epistemology is a branch of the philosophy of science which deals with the study of knowledge. It concerns questions like what is recognized as knowledge and how it can be acquired (see chapter " $>$ Philosophy of Military Sciences" by A.M. Sookermany, this volume).

Poststructuralists take issue with such a positivist epistemology. They dispute positivists' claim of unmediated access, arguing that the researcher cannot take an entirely neutral position. Our observations of the world are always mediated by our interpretations of it. Our knowledge of the world is thus not an objective truth but instead depends on how we subjectively perceive it, how we, in theoretical terms, construct it.

Take the basic realist claim that states strive for security. This claim, realists argue, is an apt description of "reality." They do not question the underlying assumptions informing this claim such as how we come to think of notions as "the state" or "security" in the first place. Poststructuralists take a step back, questioning the meaning of such notions and arguing that our understandings of them are fundamental for how we see the world and, consequently, how we act in it. What does it mean to be secure? What is the threat to be secure from? Just as a stone can be understood as a building block, a war memorial, or a weapon depending on the context, another country does not constitute a threat in itself. Whether we apprehend another country as threatening to us depends on our subjective interpretation of it.

This critical stance towards a positivist epistemology also has implications for poststructuralism's ontology, a different branch of the philosophy of science. Ontology is the study of being. It concerns questions of what is deemed to exist, what is taken into account, and what can be studied (see chapter " $>$ Philosophy of Military Sciences" by A.M. Sookermany, this volume). According to poststructuralists, what we should study - that is what is ontologically significant - is not the world out there as it is because we can never know that. Instead, we should pay attention to our interpretations of it. It is our subjective understandings of the world - the meaning that we attribute to things like, for example, another country - that are relevant for how we act. Poststructuralists' anti-foundationalist ontology - assuming that there is no hard foundation for our knowledge "out there" - thus sheds light on meaning and interpretation, on how they come into being and how they change.

But how do meaning and interpretation come into being? This is where poststructuralists' central concept comes in: Discourse. Poststructuralists attribute to language a central role in the production of meaning. The way we talk about things affects how we understand them. Discourses define what we perceive as "normal" or "natural," what we take as a given and how we look at the world. They determine what is sayable - even imaginable - in a given context. Hence, poststructuralists argue, as researchers we must study language in order to understand what interpretations guide peoples' actions. 
Poststructuralists have developed an intricate idea of how meaning and interpretations are produced in discourse. The poststructuralist understanding of language goes back to an earlier structuralist one formulated in linguistics notably by Ferdinand de Saussure (1857-1913). According to Saussure, language is a system of differences. Things do not have a meaning in themselves; the meaning attributed to them is the result of linking a thing (what structuralists call a "sign") to some things and differentiating it from others. Discourses in international politics would link "security," for example, to "peace" and differentiate it from "danger" and "war." It is through such grids of signification that we make sense of the world.

Jacques Derrida (1930-2004), an important contributor to poststructuralist thought, has taken this structuralist understanding of language further by arguing that the grid of signification is inherently unstable (Derrida, 1978). The relations of linking and differentiation between signs are not fixed but always in motion and transforming. This is why the meaning that we attribute to things can change. In international politics, for example, the notion of "security" has profoundly transformed after the end of the Cold War. Since then, its scope has been extended significantly to cover also nonconventional contexts other than war, such as natural disasters or terrorism. In its 1999 Strategic Concept, for example, NATO extended its traditional notion of security tightly linked to "defense" to also recognize "the importance of political, economic, social and environmental factors" as aspects of security (NATO, 1999). Until today, there are heated political disputes about what should be seen as a threat, ultimately also changing the meaning of "security."

From Derrida's claim that meaning is inherently unstable does not follow, however, that meaning also is always transforming. Poststructuralists show how discourses strive to fix meaning around a given structure. By articulating something in a certain way, discourses create relationships of sameness and difference and thereby structure the grid of signification. The discourse on the Global War on Terror, for example, has for two decades now linked "the West" to notions of rationality, benignancy, morality, and civilization while differentiating it from "the terrorist," which again was connotated with notions of irrationality, evil, and barbarism (Buzan \& Hansen, 2009: 243-246). Derrida has shown how Western discourses are organized around binary oppositions. Such hierarchical oppositions, or dichotomies, like man/woman, culture/nature, or, with reference to our example, morality/ barbarism are powerful signposts in the discursive structure. This structuring may appear to us as natural and just "as it is." Yet, Derrida has pointed out that any organization of dichotomic terms is not a neutral one but inherently political and normative. Most importantly, he has shown that there is no necessity to any such organization. While discursive structures can become very stable and enduring think about the persistence of gender roles in Western societies or the Global War on Terror - they can never be ultimately fixed.

This is a fundamental claim of all poststructuralists: No interpretation of the world, no meaning that we attach to it is a necessary one. No interpretation is God-given or otherwise determined. It is just one of many possibilities. This is what poststructuralists call contingency, and it is contingency which makes poststructuralism a profoundly critical project. It encourages us to look beyond the 
established order that we take for granted in our everyday life. The fact that such orders - like gender roles, for example - are often treated as "objective" knowledge illustrates what poststructuralists refer to as the power/knowledge nexus. Power and knowledge, poststructuralists argue, are inextricably linked. This understanding of power as productive goes back to Michel Foucault (1926-1984). It points to the fact that discourses establish a seemingly natural order, define what counts as "knowledge," and construct the meanings and identities through which we make sense of ourselves and the world (Foucault, 1977, 1990). Let's take a look again at the previous example of gender, which has been at the center of poststructuralist feminist studies (see, for example, Shepherd, 2008). Think of the implications the acceptance of seemingly "objective" gender roles had in the past and continuing today. This illustrates the productive power of discourse. To criticize any form of such "objective" knowledge opens up the possibility to question what seems natural to us. Another concept that for long has remained unquestioned at the center of IR theorizing is "the state." The poststructuralist critique of this concept will form the point of departure for the next section.

\section{The State and Foreign Policy}

Poststructuralism entered the IR literature during the 1980s in the context of the Second Cold War. Critical interventions by Richard Ashley (1988), Rob Walker (1993), James Der Derian and Michael Shapiro (1989) targeted how conventional approaches theorized international politics in a seemingly neutral and static way. Poststructuralists argue that the purportedly unchanging eternal truths formulated by those approaches need to be understood rather as the mirror image of a particular period in time (the modern period of sovereign states) and place (the West) (cf. Walker, 1993). This model, however, has become so entrenched that it presents itself to us as an accurate and neutral description of "reality"; and as such it has a profound impact on the analysis and formulation of foreign policy.

A major driver behind this new critical perspective on international relations was a discontent with the role of the then prevalent conception of the state. Poststructuralists do not question the centrality of states for today's international politics per se (Hansen, 2014: 176) in the same way as liberals and others have argued, for example, for a more global or more individual focus. What poststructuralists take issue with is the uncritical "taken-for-granted" attitude of traditional IR theories, such as Realism or Liberalism. Representatives of those theories, so the poststructuralist contention goes, present their view on the world as some kind of "timeless wisdom" (Buzan, 1996) - without engaging critically with the underlying core assumptions that inform those views. For realists, for example, the sovereign state is understood in abstraction from the individual as a unitary and rational actor who, following Hobbes' state of nature, finds itself in an environment of anarchy without a centralized ordering power. This notion of the state is at the center of realist thinking and therefore plays an unprecedented role for how those scholars explain international politics. 
Poststructuralists dig deeper. Inspired by French poststructuralist philosophers like Derrida and Foucault, they do not take such assumptions at face value. They scrutinize, instead, how our understandings of "the sovereign state" affect how we make sense of international relations in the first place. This was the point of departure for some of the early influential poststructuralist interventions into IR, notably the works by Ashley $(1987,1988)$ and Walker $(1990,1993,1997)$. They illustrate that the common understanding of the state rests on a dichotomy of sovereignty inside and anarchy, as its opposite, outside. Sovereignty and anarchy the national and the international - are thus understood to be mutually constitutive, that is to say they both exist only as the other's opposite. This reading of dichotomous structures reveals further binary oppositions, for example, between a rational inside and an irrational outside, between order/chaos, security/insecurity, justice/ lawlessness, effective institutions/fragile alliances, and others. Consequently, "however normal politics is understood, inter-state politics may be presented as its negation" (Walker, 1990: 15).

Ashley and Walker show how contemporary discourses perpetuate this dichotomy over and over again and thereby produce an understanding of the state as natural and objective - which they maintain it is not. By tracing the evolution of the concept of sovereignty back to its roots in the seventeenth century, Walker (1990) shows that the sovereign state is only one of several possible forms for organizing a political community. Other forms, such as hierarchical empires built on socioeconomic order from God, the Emperor, and the church, all the way down to subordinate individuals, do not seem natural in our contemporary world.

Today, its seeming objectivity makes the sovereign state in contemporary discourses the unchallenged and unquestioned form of political organization, and it is hard for us to think beyond it. In this way, dominant discourses have a strong impact on how we think and talk. Consequently, most of traditional IR theorizing unfolds within the confines of this modern discourse on the sovereign state and thereby reproduces it. By uncovering the origin and working of this discourse (that is, by showing its contingency, see above), Ashley and Walker deconstruct the traditional notion of the sovereign state. Fleshing out the dichotomies upon which it builds and how they are perpetuated in discourse, they show that the sovereign state is not a neutral description of "the world as it is," but that it is inherently normative and ideological.

\section{Self and Others}

Walker (1990) further demonstrates that the inside/outside dichotomy that sustains the dominant notion of the sovereign state is also inextricably linked to a notion of identity - that is, how we perceive ourselves. Talking about the sovereign state, he argues, implies a boundary between a community inside and Others outside. For poststructuralists, identity is a central concept because it tells us not only how someone - for example, a state - perceives itself. More importantly, it also tells us what perspective it takes on the world. Understanding a subject's identity is to 
understand how they view the world and thus illuminates why a subject acts in a certain way. To fully appreciate this argument, we require a broader context.

As the inside/outside dichotomy suggests, the poststructuralist conception of identity is inherently relational. A "Self" always defines itself in relation to "Others." Such a Self can be, for example, a state. France is France because it is not India, Brazil, or Germany. For poststructuralists, a state can be regarded as an actor in international relations because it speaks as a subject and articulates in its foreign policy a notion of "we-ness" - which poststructuralists term a notion of Self. The fundamental question for poststructuralists is: Who speaks (Epstein, 2011)? That also means, however, that poststructuralists need not limit their analyses to states as relevant actors. While the state remains the dominant form of Self in international politics, poststructuralists also take into account any other Self that is discursively articulated - for example, the European Union as a union of sovereign states or the Catalans as an ethnic group with a strong sense of identity.

Crucially, a Self is always defined through its relations to Others. William Connolly (2002) writes that "identity requires difference to be, and it converts difference into otherness in order to secure its own self-certainty" (p. 64). Identity does thus not differ from any other discursive structure that, as outlined above, is the result of processes of linking and differentiation.

Take the example of NATO. NATO's identity as a Western military alliance during the Cold War was fundamentally shaped by its opposition to the Soviet Union (Klein, 1990). After the Soviet Union ceased to exist, NATO's identity inevitably changed. Michael Williams and Iver Neumann (2000) point out how NATO's self-understanding transformed during the 1990s from one of military defense towards one of cultural or civilizational unity based on common values. Suddenly the major Other in the discourses of NATO's official documents and declarations shifted from an external Soviet threat to "instability," defined as the absence of those declared common values, notably democracy.

\section{Identity, Interests, and Foreign Policy}

The poststructuralist notion of identity as relational helps to understand how an actor perceives Others and, hence, what kind of foreign policy they might formulate towards them. Have you ever heard that a certain foreign policy-move - such as a troop deployment, a peacekeeping mission, or an intervention - was justified by saying that "it is in our interest"? Poststructuralists argue that to speak of "the national interest," as many realists frequently do, only makes sense if we understand what decision-makers consider to be in the interest of the state (Weldes, 1996). "Interests - "national' or other - are never a priori given," but always the interests of someone. "It follows that we cannot know what someone's interests are unless we know who that someone is" (Ringmar, 2002: 131). Studying identity discourses is to understand the specific interpretation of the world, that decision-makers might hold. Based on this worldview, different foreign policies may be considered detrimental or beneficial. 
This relationship between identity and foreign policy, however, is not a one-way road with the former determining the latter. Since poststructuralists assert that no meaning or identity is ever already given nor ultimately fixed - as posited by rationalist approaches - identity is also the result of discursive practices such as foreign policy. Identity and foreign policy are thus linked in both ways: Their relationship is performative, which means that they are mutually constitutive. Identity discourses facilitate and limit the formulation of particular foreign policies. Those discursive structures determine more or less rigidly what is doable, sayable, or imaginable. At the same time, foreign policies in turn have an impact on how we talk about Others and ourselves.

Take, for example, the Global War on Terror: Speaking of Iran, Iraq, and North Korea in his 2002 State of the Union address, then US President George W. Bush stated that "States like these and their terrorist allies constitute an axis of evil, arming to threaten the peace of the world" whereas America will bring "lasting peace," "liberty and justice" (Bush, 2002). Referring to terrorism and the "axis of evil," Bush discursively constructs a "civilized" Self in differentiation from this "threatening" Other. The representation - a theoretical term for how something is depicted, talked, or written about in discourse - of those countries as "axis of evil" forms the discursive background, against which the War on Terror becomes intelligible and can be justified. At the same time, this discursive background also came into being and was perpetuated through the foreign policy practices it facilitated. This performative construction of the War on Terror, however, is an ongoing process and can never be complete. Emile Simpson (2014) states that the War on Terror at least partly constitutes "a continuous effort to shape worldwide political perceptions according to the West's security interests." Because discourses can never ultimately be fixed, however, the War on Terror "[lacks] a clear end point, as perceptions continuously evolve" (p. 19).

The intimate relationship between identity and foreign policy highlights the centrality of interpretations and shared understandings for making sense of international relations. This forms the background for the topic of the next section "Security and Threat."

\section{Security and Threat}

When talking about security, notions of threat and danger take center stage. In international relations, threat and danger are inextricably linked to war and conflict. As outlined in Carsten Roennfeldt's introductory chapter to this book section, much of IR's purpose has traditionally been to avoid war and conflict.

But what is threatening? What is dangerous? Given that those questions have provoked war and conflict, determined the deployment of troops, or forged alliances, they should not be taken easily. A poststructuralist approach to those questions is hence entirely different from a rationalist one (cf. Rønnfeldt, 2021, this - "International Relations and Military Sciences" volume). Rationalists, including proponents of traditional IR theories like Realism and Liberalism, understand security largely in 
materialist terms, focusing, for example, on military capabilities (Walt, 1991). They further assume that matters of security can be assessed objectively (Hansen, 2006: 29-30; Buzan \& Hansen, 2009: 142-143). Arnold Wolfers (1952), a prominent realist, for example, claims that an "actual or objective state of danger" can - at least retrospectively - be precisely evaluated (p. 485).

Poststructuralists adopt a different perspective on security. They do not deny the reality of war and conflict. Nor do they deny the existence of obvious and immediate threats to our well-being, such as the danger of being run over by a car or the potentially deadly consequences of being hit by a bullet. As the discussion of the term "security" above suggests, however, poststructuralists argue that what is perceived as a threat is not something that can be objectively measured. Quite to the contrary: Whether we consider something dangerous is always an interpretation. To call something or someone a threat to security should therefore not be merely accepted as an objective observation but understood, instead, as a normative claim. Are troops crossing the border an aggressive attack, a liberation, or maybe part of a peacekeeping operation? Was Crimea in 2014 annexed by or reunited with Russia? The dominant discourses on this event might diverge substantially in Kyiv and Moscow. David Campbell, an early representative of poststructuralism's entry into IR, writes that "[danger] is not an objective condition. It (sic) is not a thing which exists independently of those to whom it may become a threat" (1992: 1). What security is, is fundamentally tied to our perspective on the world and can therefore never be discussed in separation from who we are. Walker (1997) asserts that our understanding of security is derived from an idea of "who or what it is that needs to be secured" (p. 68). Talking about security in the context of international relations therefore inevitably reasserts a certain identity. Discourses of security, however, not only constitute and reaffirm who we are. They also define who or what the threatening Other is from which we need to be protected. They establish categories of Self and Other, friends and enemies. Do you remember from the last section that identity is relational? Poststructuralists assert that security discourses are central for constructing such Others to which the Self relates.

\section{Changing Threats}

A seminal study on the construction of enemies during the Cold War was presented by Campbell in his book Writing Security (1992). According to him, threat and danger are a fundamental necessity for the state to exist. The state, Campbell argues, relies on the articulation of outside threats against which it can define the inside. From this perspective, the Cold War was much more than a military confrontation between two superpowers. On the US side, it was a process through which discourses on the dangers of communism and the Soviet threat continuously (re)produced a particular US identity. Campbell also shows how those discourses of threat and danger served to discipline dissident elements within the country. Discursively linking those "internal Others" to an external threat delegitimizes their cause and justifies their persecution. 
Campbell goes as far as to say that "[should] the state project of security be successful in the terms in which it is articulated, the state would cease to exist." (p. 12). His argument thus suggests that the West would suffer from a major identity crisis after the collapse of its radical Other, the Soviet Union. At the time, poststructuralism was grabbling with the question of whether states need enemies (Buzan \& Hansen, 2009: 218), and the changing security discourses produced a more nuanced understanding of it.

With the Gulf War of 1990-1991 and the conflicts in Bosnia and Kosovo, the theme of military interventions in other states became more pronounced. Was Campbell's notion of the radical threatening Other still apt to make sense of those new contexts? In her book Simulating Sovereignty (1995), Cynthia Weber analyzes how justifications for such interventions have evolved over time. She finds that the discourses legitimizing interventions frequently invoke "the people," which must be protected from their own government. Similar to NATO's shifting selfunderstanding after the Cold War as illustrated above, Barry Buzan and Lene Hansen (2009) argue that the increasing prevalence of the humanitarian interventiondiscourse in the 1990s also changed the identity of "the West." Poststructuralist studies now identified as the central Other not the radical threat anymore that Campbell found during the Cold War. Instead, the discourses invoked the "humanitarian 'victim' in need of a 'rescue'," which depoliticized and thereby helped to legitimize Western interventionist policies (pp. 219-220).

All this is to show that poststructuralists have a deep interest in security. They are not concerned, however, with security as an objective state like rationalists such as realists and liberals would have it. They are interested, instead, in understanding how security discourses bring into existence an understanding of ourselves and Others, friends and enemies. When dealing with conflicts, this poststructuralist approach cautions us to be aware that there is certainly more than one "objective" interpretation of it. When engaging with complex settings, such as Afghanistan, one should therefore be wary of a simple division into friends and enemies. This is because others implicated in the conflict - the broader public, nongovernmental actors, neighboring states, or an international audience - might have different interpretations of it and, possibly, identify different threats or draw the friend-enemy line differently. The same act, for example, a counterinsurgency operation, can be perceived vastly differently by different audiences, because different discourses will offer different frameworks for making sense of the operation. Poststructuralists suggest that an awareness of the different discourses prevalent within a conflict is crucial for those analyzing or engaging with it - at a policy, strategic, or tactical level.

\section{Securitization}

"Securitization" theory offers another insightful perspective on security. While not a poststructuralist approach in the narrow sense, securitization theory 
points our attention to security dynamics that are equally interesting to poststructuralists, namely the role of language and representation in and for international politics. Securitization has sparked a broader discussion in the field of IR. A distinction, for example, is often made between a "Copenhagen School" and a more sociologically oriented "Paris School" (cf. Wæver, 2004). The former can be traced in particular to Barry Buzan, Ole Wæver, and Jaap de Wilde's Security: A New Framework For Analysis (1998).

Buzan et al.'s point of departure is the widening security agenda since the 1970s and 1980s (Wæver, 2004: 8). This widening was a reaction to the narrow focus on military matters during the Cold War (Fierke, 2015: 1-2). While generally sympathetic to that move, Buzan et al. (1998) pose the question of what it means that nonmilitary issues, for example, environmental, economic, or social phenomena, were increasingly framed as problems of security. Irrespective of the sector, they argue, this framing follows the same underlying logic. This is what Buzan et al. term "securitization": An issue is presented - for example, by a politician - as an existential threat that requires emergency measures and this claim is accepted as such by the audience. Such an issue could be the amassing of foreign troops at the border, environmental pollution, or migration. Think of the role the alleged - and later on never found - Weapons of Mass Destruction of the Hussein-Regime played in public discourse prior to the Iraq war in 2003 (cf. Donnelly, 2013). In the 2002 State of the Union Address, Bush said "By seeking weapons of mass destruction, these regimes pose a grave and growing danger. They could provide these arms to terrorists, giving them the means to match their hatred. They could attack our allies or attempt to blackmail the United States. In any of these cases, the price of indifference would be catastrophic." (Bush, 2002). Bush clearly insinuates that doing nothing would pose an existential threat to the United States and therefore suggests to act accordingly.

Securitization is not unproblematic, however. Because "'Security" is the move that takes politics beyond the established rules of the game" (Buzan et al., 1998: 23), securitization withdraws an issue from the usual political process. The justification of exceptional measures through security thwarts the careful deliberation of an issue and may even circumvent established democratic procedures and institutions.

Consequently, in order to soberly weigh and evaluate delicate issues from various perspectives, Buzan et al. (1998) argue in favor of desecuritizing them: "the shifting of issues out of emergency mode and into the normal bargaining process of the political sphere" (p. 4).

Securitization theory, just like poststructuralists, treats security primarily as a matter of subjective interpretation: "'Security' is [...] a self-referential practice, because it is in this practice that the issue becomes a security issue - not necessarily because a real existential threat exists but because the 
issue is presented as such a threat" (Buzan et al., 1998: 24). This underlines the role shared interpretations play for foreign and security policies. Consequently, the task of the researcher "is not to assess some objective threats that 'really' endanger some object to be defended or secured; rather, it is to illuminate the processes of constructing a shared understanding of what is to be considered and collectively responded to as a threat." (p. 26). The next section will outline in greater detail how we as researchers can shed light on such discursive dynamics in the context of international relations.

\section{Analyzing Discourse}

The preceding sections introduced the poststructuralist perspective on international relations. For many, this perspective is not the most intuitive and accessible one. Once you come to realize, however, the role subjective interpretations play in international politics, you will recognize how powerful a poststructuralist inquiry into their constitution and working can be. But how can you make this theoretical perspective work for your empirical analysis? This section will outline some methodological considerations when studying discourse. It will first clarify the research logic of poststructuralist inquiries before presenting the method of poststructuralist discourse analysis (For an overview of different traditions of discourse analysis, see Jørgensen and Phillips (2002)).

\section{A Poststructuralist Research Logic}

Like any inquiry in our field, let us start this methodological intro with the research question. Unlike more traditional, rationalists IR theories like Realism or Liberalism, poststructuralists do not ask research questions that follow a causal why-logic, such as "why does country A attack country B"? This kind of question requires the identification of distinct causes that can explain a given outcome. Such a causal description can only make sense within a positivist framework that, as you will remember, is built on the assumption of objective knowledge about the world.

Poststructuralists, on the other hand, are concerned with how the meaning and identities that form the context of our actions are constituted and how they change. Poststructuralist inquiries shed light on the particular discursive structures that facilitate certain practices - or policies - make them thinkable and doable within a given discursive context. In short, they analyze discourse in order to understand its "implications [...] for the way we think and act in the contemporary world" (George, 1994: 191). Poststructuralist research questions therefore follow a how possiblelogic. An example could be: "How does country B come to be represented as a threat in country A's foreign policy discourse?" An answer to this question can help to 
understand how a conflict between country A and B becomes possible in the first place. Importantly, poststructuralists always keep in mind that there is no necessity to any given discourse and that it is only one of many possibilities. As you will remember, this is called the "contingency" of discourse. Even if in our view the representation of country B as threatening seems "natural" or "objective," poststructuralists will maintain that this is just one of many possible interpretations and that no discourse is constituted irrevocably. This is where deconstruction comes in: The seeming objectivity of a discourse is unmasked by showing how this particular discourse works, for example, what dichotomies sustain the representation of country $\mathrm{B}$ as threatening.

Whether country B has come to be understood as a friend or a foe will facilitate vastly different policy options. To analyze a given discourse thus also means to "[consider] the manifest political consequences of adopting one mode of representation over another" (Campbell, 1992: 4). To sum up, discourse analysists seek to capture how meaning is discursively produced and how it changes, as well as the implications of one particular discourse over other possible ones.

\section{Translating Theory into Practice}

Against this background: How to carry out a discourse analysis in practice? Because poststructuralists are interested in profoundly understanding a given context, their analyses are based first and foremost on qualitative data. This could be any text, such as a speech, an interview, or a newspaper article. A close investigation thereof is aimed at understanding the underlying discursive structure, "how signs are linked and juxtaposed, how they construct Selves and Others, and how they legitimize particular policies" (Hansen, 2006: 41). While every articulation forms part of discourse and therefore lends itself for analysis, understanding discourse as producing shared understandings suggests taking into account a broader set of texts (Milliken, 1999: 233). But how many? And when to stop? To this, Jennifer Milliken (1999) responds that an "analysis can be said to be complete (validated) when upon adding new texts $[\ldots]$, the researcher finds consistently that the [discursive structures] she has generated work for those texts" (p. 234).

There is no ready-made template for how to carry out a poststructuralist discourse analysis. As a "problem-driven" approach (Howarth, 2005), every discourse analysis ought to be tailored to the research interest in question. Lene Hansen's book Security as Practice (2006) constitutes a comprehensive guide to discourse analytical research designs. She highlights four parameters in particular that should be taken into account when devising an empirical analysis (pp. 65-82). In order to illustrate how to approach discourse analytical inquiries, the following paragraph will provide a simplified overview of Hansen's four parameters. A promising research design will take each of them into account. As with every methodology, this requires you to take many informed decisions and to justify your choices.

An empirical inquiry must, first, specify whose discourses it focusses on. Are you looking at the foreign policy discourse of one or more Selves? Who is speaking 
(cf. Epstein, 2011)? Are you focusing on one or more states or other foreign policy subjects?

A second parameter to be determined is what event the respective discourse is about. This could be any issue in international politics: A conflict such as the ongoing crisis in Ukraine or a topic like climate change. An example: Analyzing Russia's foreign policy discourse on the events in Ukraine, how it represents the Russian Self, the Ukrainian, and the Western Others can be helpful for understanding how this discourse facilitated certain Russian foreign policies towards Ukraine and how it precluded others.

A concise analysis, thirdly, requires a clarification of where to look for a specific discourse. What is the discursive arena of interest? Are you taking into account only the Russian government's official rhetoric, or are you broadening the scope of your study by also including the wider foreign policy debate as articulated by other political figures or in the media? To study media discourses can be helpful in order to gauge the room of maneuver politicians find themselves in. After all, this constitutes the discursive context in which policy-makers formulate, explain, and justify foreign policies. For an even broader inquiry, it might also be insightful to consider discourse as articulated in cultural sources (see, for example, Der Derian, 1992, and Shapiro, 1988, 1990).

A final parameter Hansen (2006) points out is the temporal dimension of an inquiry, the when. What time frame are you taking into account? Are you looking at one particular moment, or are you comparing different periods? To pick up the example above, you could focus your analysis of Russian foreign policy discourse on key moments in the Ukraine crisis, such as the Maidan protests or the annexation of Crimea. Alternatively, you could also choose a more long-term perspective to illuminate how representations, for example, of Ukraine or "the West," have evolved over time in the Russian discourse.

To trace the development of a specific representation or concept is to study its "genealogy." Foucault has coined this notion as "history of the present." A genealogical inquiry seeks "to show 'descent' and 'emergence' and how the contingencies of these processes continue to shape the present" (Garland, 2014: 371; cf. Foucault, 1984: 76-100). The aim is thus to show that what now may be taken for granted has not always been understood in this way but is, in fact, the outcome of a series of forgotten struggles in the past that might as well have turned out differently. Some groups of people might have had a greater impact in this process because others were marginalized or not allowed to speak. A famous example of a genealogical inquiry is provided by Edward Said's book Orientalism (1978). Said traces how the representations of "the Orient" have evolved in Western European intellectual discourses since the eighteenth century. He shows how those representations, that continue to impact the Western perception of the East, were discursively constructed in contrast to a superior "occidental" Self, thereby simultaneously reflecting and perpetuating European racism and imperialism. As such, a genealogical inquiry not only illuminates what changes and/or continuities a certain concept underwent and how our present thinking came about. Importantly, by exposing how the productive power of discourses established seemingly objective meanings and identities, it is a reminder 
that much of the understandings that guide our thinking and acting today are a contingent outcome of the past, and it therefore encourages us to question them.

\section{Conclusion}

This chapter aimed to show that discourse - the way we talk about the world, about ourselves and others - matters. It brings into being our understanding of the world and as such cannot be separated from our thinking and acting. Discourses construct what is considered "natural" or "objective." The poststructuralist project does not accept those established orders as "natural" and points to the contingency of discourse, that is, of any meanings and identities.

This poststructuralist approach has also encountered criticism. Two often articulated critiques merit a quick critical review. The first one concerns poststructuralism's epistemology - as you remember, this philosophical term concerns the question of what counts as knowledge. Representatives of traditional approaches have accused poststructuralists and other so-called reflectivists (cf. Rønnfeldt, 2021, this volume) of lacking "a coherent research program" (Keohane, 1988: 379) that would meet scientific standards. This judgement is shortsighted, however, because poststructuralists take issue with those standards in the first place. Robert Keohane and others thus fail to acknowledge the divergent epistemological positions poststructuralists take on what counts as knowledge.

A second line of criticism (cf. Brown, 1994) takes issue with poststructuralists' anti-foundationalist ontology. As you will remember, poststructuralists claim that there is no hard foundation for our knowledge "out there" and that the meaning we attach to things is a discursive construction instead. Critics have dismissed such a worldview as "relativist" or "nihilistic" and claimed that it rids one of the ability to distinguish right from wrong. This accusation, however, mistakes poststructuralists' rejection of transcendental foundations as a wholesale rejection of the fact that things do exist. For example, poststructuralists do not question or reject the existence of "the state" as a contemporary form of political organization. They simply point out that "the state" is a contingent result of historical processes that could as well have taken different turns. It therefore should be regarded as one possibility of many instead of a neutral description of simply "how it is." Poststructuralists' mission, so to say, is not to eliminate a certain way of thinking, but to highlight that this particular way of thinking is not God-given or neutral.

Poststructuralism has much to offer for anyone interested in and working with international affairs, military professionals included. Its analytical approach reminds us that there is no objective, no God-given, foundation to our understandings of the state, threats, foreign policy, and other aspects of international relations. Instead, the meaning individuals attach to the world and their respective behavior are shaped by and at the same time shape the discourses that they are implicated in. From the point of view of the military, special attention ought to be paid to discourses of security. It is through discourses of security that the use of armed force is typically justified. Whether or not something, for instance another state, a militant organization, or 
migration, is perceived as a threat has far-reaching consequences for a country's foreign policy decisions. Like any foreign policy discourse, talking about security is intimately linked to how we see the world and what policies we deem appropriate. It is therefore important to keep in mind that "threats" are no objective conditions, but normative, political representations. Instead of taking them at face value, poststructuralists argue, we as researches should ask how those discourses work to structure, facilitate, and, at the same time, limit our thinking and acting within the established order. There is no escape from discourse, but being aware of how they work is a precondition for being critical about them and questioning seemingly objective "truths."

\section{Cross-References}

International Relations and Military Sciences

Realist International Relations Theory and the Military

- Liberal International Relations Theory and the Military

- Philosophy of Military Sciences

\section{References}

Ashley, R. K. (1987). The geopolitics of geopolitical space: Toward a critical social theory of international politics. Alternatives: Global, Local, Political, 12(4), 403-434. https://doi.org/10. 1177/030437548701200401.

Ashley, R. K. (1988). Untying the sovereign state: A double Reading of the anarchy Problematique. Millennium: Journal of International Studies, 17(2), 227-262. https://doi.org/10.1177/ 03058298880170020901.

Baumann, M. (2020). 'Propaganda fights' and 'disinformation campaigns': The discourse on information warfare in Russia-west relations. Contemporary Politics, 26(3), 288-307. https:// doi.org/10.1080/13569775.2020.1728612.

Brown, C. (1994). 'Turtles all the way down': Anti-foundationalism, critical theory and international relations. Millennium: Journal of International Studies, 23(2), 213-236. https://doi.org/ 10.1177/03058298940230020901.

Bush, G. W. (2002). President delivers state of the union address. White House. https:// georgewbush-whitehouse.archives.gov/news/releases/2002/01/20020129-11.html.

Buzan, B. (1996). The timeless wisdom of realism? In S. Smith, K. Booth, \& M. Zalewski (Eds.), International theory (1st ed., pp. 47-65). Cambridge University Press. https://doi.org/10.1017/ CBO9780511660054.004.

Buzan, B., \& Hansen, L. (2009). The evolution of international security studies. Cambridge University Press.

Connolly, W. E. (2002). Identity, difference: Democratic negotiations of political paradox (Expanded ed). University of Minnesota Press.

Der Derian, J. (1992). Antidiplomacy: Spies, terror, speed, and war. Blackwell.

Der Derian, J., \& Shapiro, M. J. (Eds.). (1989). International/intertextual relations: Postmodern readings of world politics. Lexington Books.

Derrida, J. (1978). Writing and difference. University of Chicago Press.

Donnelly, F. (2013). Securitization and the Iraq war: The rules of engagement in world politics. Routledge. 
Epstein, C. (2011). Who speaks? Discourse, the subject and the study of identity in international politics. European Journal of International Relations, 17(2), 327-350. https://doi.org/10.1177/ 1354066109350055.

Fierke, K. M. (2015). Critical approaches to international security (2nd ed.). Polity Press.

Foreign Policy. (2018). Here's what Trump and Putin actually said in Helsinki. The press conference transcript - And what the White House edited out. https://foreignpolicy.com/2018/07/18/ heres-what-trump-and-putin-actually-said-in-helsinki/

Foucault, M. (1977). Discipline and punish: The birth of the prison (1st American ed). Pantheon Books.

Foucault, M. (1984). In P. Rabinow (Ed.), The Foucault reader (1st ed.). Pantheon Books.

Foucault, M. (1990). The history of sexuality. Vol. 1: An introduction (Reprint, Vol. 1). Penguin Books.

Garland, D. (2014). What is a "history of the present"? On Foucault's genealogies and their critical preconditions. Punishment \& Society, 16(4), 365-384. https://doi.org/10.1177/ 1462474514541711.

George, J. (1994). Discourses of global politics: A critical (re)introduction to international relations. Lynne Rienner [u.a.].

Hansen, L. (2014). Poststructuralism. In J. Baylis \& S. Smith (Eds.), The globalization of world politics: An introduction to international relations (6th ed., pp. 169-183). Oxford University Press.

Howarth, D. (2005). Applying discourse theory: The method of articulation. In D. Howarth \& J. Torfing (Eds.), Discourse theory in European politics (pp. 316-350). Palgrave Macmillan UK. https://doi.org/10.1057/9780230523364.

Jørgensen, M., \& Phillips, L. (2002). Discourse analysis as theory and method. Sage Publications.

Keohane, R. O. (1988). International institutions: Two approaches. International Studies Quarterly, 32(4), 379. https://doi.org/10.2307/2600589.

Klein, B. S. (1990). How the west was one: Representational politics of NATO. International Studies Quarterly, 34(3), 311. https://doi.org/10.2307/2600572.

Landler, M., \& Haberman, M. (2018, July 17). A besieged trump says he misspoke on Russian election meddling. The New York Times. https:/www.nytimes.com/2018/07/17/world/europe/ trump-putin-summit.html?

Milliken, J. (1999). The study of discourse in international relations: A critique of research and methods. European Journal of International Relations, 5(2), 225-254. https://doi.org/10.1177/ 1354066199005002003.

NATO. (1999). The alliance's strategic concept. https://www.nato.int/cps/en/natohq/official_texts_ 27433.htm

Ringmar, E. (2002). The recognition game: Soviet Russia against the west. Cooperation and Conflict, 37(2), 115-136. https://doi.org/10.1177/0010836702037002973.

Said, E. W. (1978). Orientalism (1st ed.). Pantheon Books.

Shapiro, M. J. (1988). The politics of representation: Writing practices in biography, photography, and policy analysis. University of Wisconsin Press.

Shapiro, M. J. (1990). Strategic discourse/discursive strategy: The representation of 'security policy' in the video age. International Studies Quarterly, 34(3), 327. https://doi.org/10.2307/ 2600573.

Shepherd, L. J. (2008). Gender, violence and security: Discourse as practice. Zed Books. Distributed exclusivelyin the USA by Palmgrave Macmillan.

Simpson, E. (2014). War from the ground up: Twenty-first century combat as politics. Oxford University Press. https://public.ebookcentral.proquest.com/choice/publicfullrecord.aspx? $\mathrm{p}=4704139$.

Wæver, O. (2004). Aberystwyth, Paris, Copenhagen: New schools in security theory and their origins between core and periphery. 45th Annual Meeting of the International Studies Association, Montreal. 
Walker, R. B. J. (1993). Inside/outside: International relations as political theory. Cambridge University Press.

Walker, R. B. J. (1997). The subject of security. In K. Krause \& M. C. Williams (Eds.), Critical security studies: Concepts and cases. University of Minnesota Press.

Walt, S. M. (1991). The renaissance of security studies. International Studies Quarterly, 35(2), 211. https://doi.org/10.2307/2600471.

Weber, C. (1995). Simulating sovereignty: Intervention, the state, and symbolic exchange. Cambridge University Press.

Weldes, J. (1996). Constructing National Interests. European Journal of International Relations, 2(3), 275-318. https://doi.org/10.1177/1354066196002003001.

Williams, M. C., \& Neumann, I. B. (2000). From Alliance to security community: NATO, Russia, and the power of identity. Millennium: Journal of International Studies, 29(2), 357-387. https:// doi.org/10.1177/03058298000290020801.

Wolfers, A. (1952). 'National Security' as an ambiguous symbol. Political Science Quarterly, 67(4), 481. https://doi.org/10.2307/2145138.

\section{Further Reading}

Buzan, B., Wæver, O., \& de Wilde, J. (1998). Security: A new framework for analysis. Lynne Rienner Publications.

Campbell, D. (1992). Writing security: United States foreign policy and the politics of identity. University of Minnesota Press.

Doty, R. L. (1997). Aporia: A Critical Exploration of the Agent-Structure Problematique in International Relations Theory. European Journal of International Relations, 3(3), 365-392. https://doi.org/10.1177/1354066197003003004.

Edkins, J. (1999). Poststructuralism \& international relations: Bringing the political back in. Lynne Rienner Publishers.

Hansen, L. (2006). Security as practice: Discourse analysis and the Bosnian war. Routledge.

Laclau, E., \& Mouffe, C. (1985). Hegemony and socialist strategy: Towards a radical democratic politics. Verso.

Walker, R. B. J. (1990). Security, sovereignty, and the challenge of world politics. Alternatives: Global, Local, Political, 15(1), 3-27. https://doi.org/10.1177/030437549001500102.

Open Access This chapter is licensed under the terms of the Creative Commons Attribution 4.0 International License (http://creativecommons.org/licenses/by/4.0/), which permits use, sharing, adaptation, distribution and reproduction in any medium or format, as long as you give appropriate credit to the original author(s) and the source, provide a link to the Creative Commons license and indicate if changes were made.

The images or other third party material in this chapter are included in the chapter's Creative Commons license, unless indicated otherwise in a credit line to the material. If material is not included in the chapter's Creative Commons license and your intended use is not permitted by statutory regulation or exceeds the permitted use, you will need to obtain permission directly from the copyright holder.

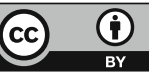

